$36: 36$

$<$ 症例報告 $>$

$$
\begin{gathered}
\text { 肝細胞癌に対する chemolipiodolization 後に上腹部 } \\
\text { 皮下組織が壊死に陌った } 1 \text { 例 }
\end{gathered}
$$

$\begin{array}{llllrll}\text { 小池 } & \text { 和彦 } & \text { 伊坪真理子 } & \text { 原 } & \text { 正樹 } & \text { 榎本 } & \text { 康之 } \\ \text { 奥田 } & \text { 丈二 } & \text { 穂苅 厚史 } & \text { 奥秋 } & \text { 靖 } & \text { 坂口 } & \text { 正巳 } \\ \text { 河辺 } & \text { 朋信 } & \text { 戸田剛太郎* } & & & & \end{array}$

要 旨：症例は57歳男性. 肝硬変として外来に通院中, 血清 $\mathrm{AFP}$ 值の上昇と腹部超音波検査に て肝内腫瘤像を指摘された。肝動脈造影にて肝 S8領域に腫湯濃染像を認めたため肝細胞癌と診 断, 右肝動脈前上行枝より肝動脈塞栓術を行った. 4 力月後に一旦低下傾向を示した血清 AFP 值が再上昇したため血管造影を施行した. 肝 S1領域に新たな腫瘍病変がみられたため左肝動脈 内側枝から分岐する腫晹栄養動脈より chemolipiodolization を行ったが，治療後に上腹部皮下 組織壊死が出現した。本症例は, 肝動脈造影時に左肝動脈より分枝し肝円索に伴行する hepatic falciform artery と思われる特異な動脈枝が描出されており，この細動脈の支配する上腹部皮 下組織が chemolipiodolization による化学毒性と虚血に陷ったことが主因と考えられた。極め て稀な合併症であるものの示唆に富む症例と考えられ報告した.

索引用語：肝細胞癌 chemolipiodolization

hepatic falciform artery

\section{はじめに}

肝細胞癌に対する血管カテーテル治療は, 肝予備能 が低下し手術適応のない肝細胞癌合併症例における治 療方法としての多数の施設にて行われ，現在，その有 用性が確立されているい6\}. しかし，一方では血管力 テーテル治療に伴い，正常組織が虚血に陥ることによ る合併症も少なからず報告されている7 18). 今回われ われは, 肝円索に伴行する hepatic falciform artery と思われる特異な動脈枝を諗める肝細胞癌症例におい $て$, chemolipiodolization 後に上腹部皮下組織が限局 性壊死に陥った一例を経験したのでここに報告する。

$$
\text { 症例 }
$$

患者：57歳，男性.

主訴：肝内腫瘤の精查加潦.

家族歴：父が肝細胞癌にて死亡. 姝が C 型慢性肝炎 にて他院通院中.

既往歴：18歳, 虫垂炎にて手術，54墄，髄膜炎・糖
尿病。

輸血歴：なし。

飲酒歴：日本酒 5 合/日，30年間（積算飲酒量 1,100 $\mathrm{kg}$ ).

現病歴：1991年に韨膜炎にて近医入院。この時，は じめて HCV 抗体陽性の肝障害と耐糖能障害を指摘さ れた. 腹部超音波検査所見をふまえ, C 型肝炎ウイルス 感染㧍よびアルコール多飲が原因と考えられる肝硬変 および楉尿病と診断された，以来，同院にて加療され ていたが, AFP 值の上昇および腹部超音波検査にて肝 右葉前上区域（S8）に腫瘤像が認められたため，肝細 胞癌の疑いにて当科を紹介され，1993年 5 月，当科第 一回目入院となった。

第一回入院時現症：身長 $172 \mathrm{~cm}$, 体重 $63.5 \mathrm{~kg}$, 血圧 $118 / 88 \mathrm{mmHg}$, 体温 $36.0^{\circ} \mathrm{C}$, 脈拍 $68 / \mathrm{min}$ 整. 意識は清 明，結膜に黄染，垻血を認めず。胸部に聴打診上，異 常を認めず，腹部では肝腪を触知せず，腹水，浮腫も

Kazuhiko Kolke, Mariko Itsubo, Masaki Hara, Yasuyuki Enomoto, Jyoji OkudA, Atsushi Hokari, Yasushi OKUAKI, Masami SaKaguchi, Tomonobu Kawabe and Gotarou TOdA*

*東京慈恵会医科大学内科学第 1 講座

<受付日1995年 6 月12日 $>$ 
Table Laboratory data on the first admission.

\begin{tabular}{|c|c|c|c|c|c|}
\hline \multicolumn{2}{|c|}{ Peripheral blood } & \multirow{2}{*}{$\begin{array}{l}\text { TP } \\
\text { Alb }\end{array}$} & \multirow{2}{*}{$\begin{array}{c}7.0 \mathrm{~g} / \mathrm{d} l \\
49 \%\end{array}$} & \multicolumn{2}{|l|}{ Tumor markers } \\
\hline WBC & $5,300 / \mu l$ & & & $\mathrm{AFP}$ & $640 \mathrm{ng} / \mathrm{m} l$ \\
\hline $\mathrm{RBC}$ & $441 \times 10^{4} / \mu l$ & $\alpha_{1}$-glob. & $49 \%$ & PIVKA-II & $<0.06 \mathrm{AU} / \mathrm{m} l$ \\
\hline $\mathrm{Hb}$ & $14.9 \mathrm{~g} / \mathrm{d} l$ & $\alpha_{2} \cdot$ glob. & $9.5 \%$ & DUPAN-2 & $800 \mathrm{U} / \mathrm{m} l$ \\
\hline $\mathbf{H t}$ & $43.2 \%$ & $\beta$-glob. & $13 \%$ & CA19-9 & $160 \mathrm{ng} / \mathrm{ml}$ \\
\hline Plt & $10.8 \times 10^{4} / \mu l$ & $\gamma$-glob. & $26 \%$ & Virus markers & \\
\hline \multicolumn{2}{|c|}{ Coagulation test } & BUN & $31 \mathrm{mg} / \mathrm{d} l$ & HBsAg & $(-)$ \\
\hline $\mathrm{PT}$ & $96 \%$ & $\mathrm{Cr}$ & $1.3 \mathrm{mg} / \mathrm{d} l$ & anti-HBs & $(-)$ \\
\hline APTT & $29.6 \mathrm{sec}$ & UA & $7.3 \mathrm{mg} / \mathrm{d} l$ & HCVAb (II) & $(+)$ \\
\hline Fib & $250 \mathrm{mg} / \mathrm{d} l$ & $\mathrm{Na}$ & $134 \mathrm{mEq} / l$ & Urinalysis & \\
\hline HPT & $88 \%$ & $\mathrm{~K}$ & $4.9 \mathrm{mEq} / \mathrm{l}$ & S.G. & 1.010 \\
\hline Blood $\mathrm{Ch}$ & stry & $\mathrm{Cl}$ & $103 \mathrm{mEq} / l$ & $\mathrm{pH}$ & 6.0 \\
\hline AST & $109 \mathrm{mU} / \mathrm{m} l$ & TC & $239 \mathrm{mg} / \mathrm{d} l$ & protein & $(-)$ \\
\hline ALT & $155 \mathrm{mU} / \mathrm{m} l$ & TG & $177 \mathrm{mg} / \mathrm{d} l$ & sugar & $(+)$ \\
\hline LDH & $304 \mathrm{mU} / \mathrm{m} l$ & HDL-chol. & $44 \mathrm{mg} / \mathrm{d} l$ & urobilinogen & $( \pm)$ \\
\hline ChE & $249 \mathrm{mU} / \mathrm{ml}$ & $\mathrm{NH}_{3}$ & $34 \mu \mathrm{mol} / l$ & acetone & $(-)$ \\
\hline T. Bil & $1.1 \mathrm{mg} / \mathrm{d} l$ & CRP & $0.2 \mathrm{mg} / \mathrm{d} l$ & bilirubin & $(-)$ \\
\hline D. Bil & $0.4 \mathrm{mg} / \mathrm{d} l$ & FBS & $295 \mathrm{mg} / \mathrm{d} l$ & occult blood & $(+)$ \\
\hline ALP & $368 \mathrm{mU} / \mathrm{ml}$ & $\mathrm{HbAlc}$ & $12.7 \%$ & U.protein & $0.06 \mathrm{~g} / \mathrm{day}$ \\
\hline LAP & $612 \mathrm{GRu}$ & $\operatorname{ICG}\left(R_{15}\right)$ & $34 \%$ & U-sugar & $2.38 \mathrm{~g} /$ day \\
\hline$\gamma \mathrm{GTP}$ & $226 \mathrm{mU} / \mathrm{m} l$ & $\mathrm{CCr}$ & $56 \mathrm{ml} / \mathrm{min}$ & & \\
\hline TTT & $3.9 \mathrm{U}$ & & & & \\
\hline ZTT & $12.2 \mathrm{U}$ & & & & \\
\hline
\end{tabular}

認めなかった，神経学的所見では，髄膜炎後遺症と思 われる高度の両側聴力障害を認めた。

第一回入院時検査成績 (Table)：末梢血一般では血 小板数の減少を, 血液生化学検查では AST, ALT, $\gamma \mathrm{GTP}$ の中等度上昇とコリンエステラーゼ, アルブミ ンの軽度低下がみられた。 ICG 15 分停滞率は $34 \%$ と ICG 血中消失遅延を認めた。血清 AFP 值は $640 \mathrm{ng} / \mathrm{m} l$ と上昇していた。糖尿病のコントロールは不良であり， 軽度の腎機能障害も認めた。

腹部 CT 所見 (Fig. 1)：入院時施行した腹部 CT 検 查では, 肝左葉の腫大および脾腫を認め, 肝 S8領域に 腹部超音波検查にて指摘された腫瘤を径 $20 \mathrm{~mm}$ 大の低 吸収域として認めた。

第一回肝動脈造影：1993年 5 月27日施行した一回目 の肝動脈造影では，右肝動脈前上行枝領域に径 $20 \mathrm{~mm}$ 大の腫第濃染像を認め肝細胞癌と診断した (Fig. 2a). 血液生化学検査でコリンエステラーゼ, アルフミン值 の低下を認め, また, ICG 血中消失遅延より肝予備能 の低下が考えられた、コントロール不良な糖尿病の合 併もあり肝切除術の適応でないと考え，同部に対して 右肝動脈前上行枝より塩酸 epirubicin $40 \mathrm{mg}$, lipiodol $4 \mathrm{~m} l$, gelfoam 細片にて肝動脈塞栓術（TAE）を施行 した。この際, 左肝動脈より分枝し肝円索に伴行する

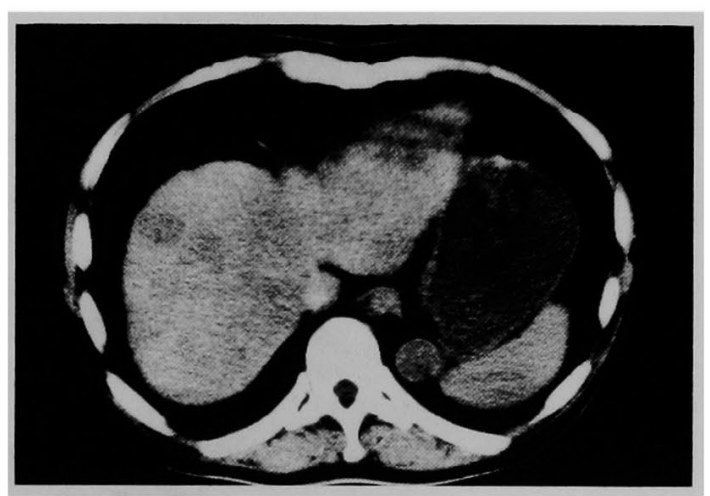

Fig. 1 Abdominal plain CT scan. A low density area in segment 8 of the liver, approximately 20 $\mathrm{mm}$ in diameter, was seen.

hepatic falciform artery と思われる動脈枝の存在を 認めた (Fig. 2b).

臨床経過：退院後の外来経過観察にて, $240 \mathrm{ng} / \mathrm{m} l$ まで低下した AFP 值が $810 \mathrm{ng} / \mathrm{m} l$ まで再度上昇した ため, 同年10月, 二回目の入院となった。1993年10月 27日施行した二回目の肝動脈造影では, 初回肝動脈造 影にて認めた右肝動脈前上行枝領域の腫湯漂染像は消 失していた (Fig. 3a) が, 新たな腫瘍病変を肝 S1領域 


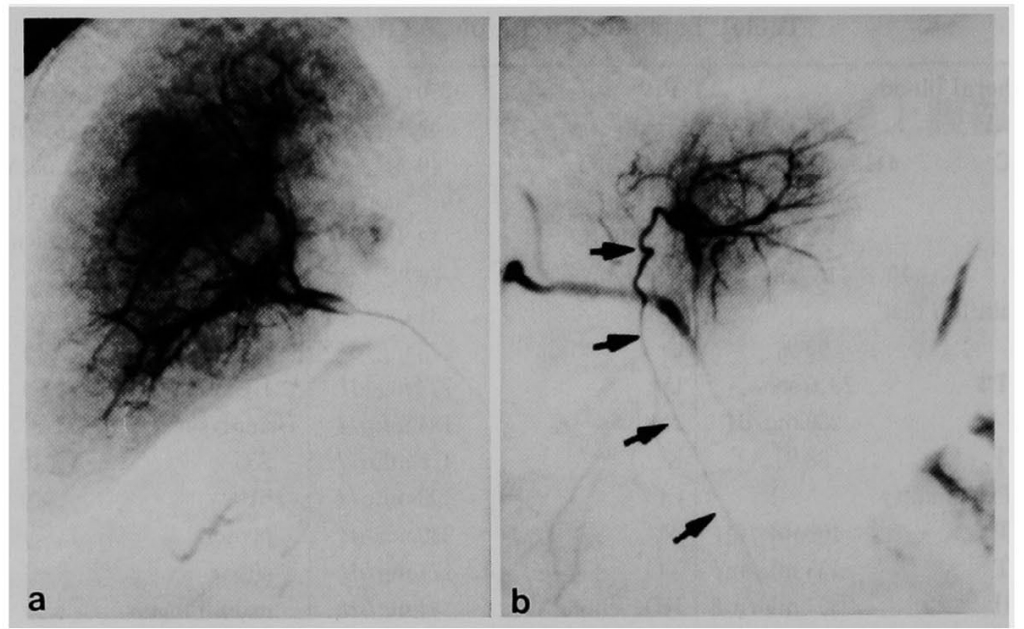

Fig. 2 The hepatic arteriogram at the first time.

a : A hypervascular lesion in segment 8 of the liver, approximately $20 \mathrm{~mm}$ in diameter, was seen. b : A fine vessel (arrow) branching from the left hepatic artery, considered to be the hepatic falciform artery running along the round ligament, was seen.

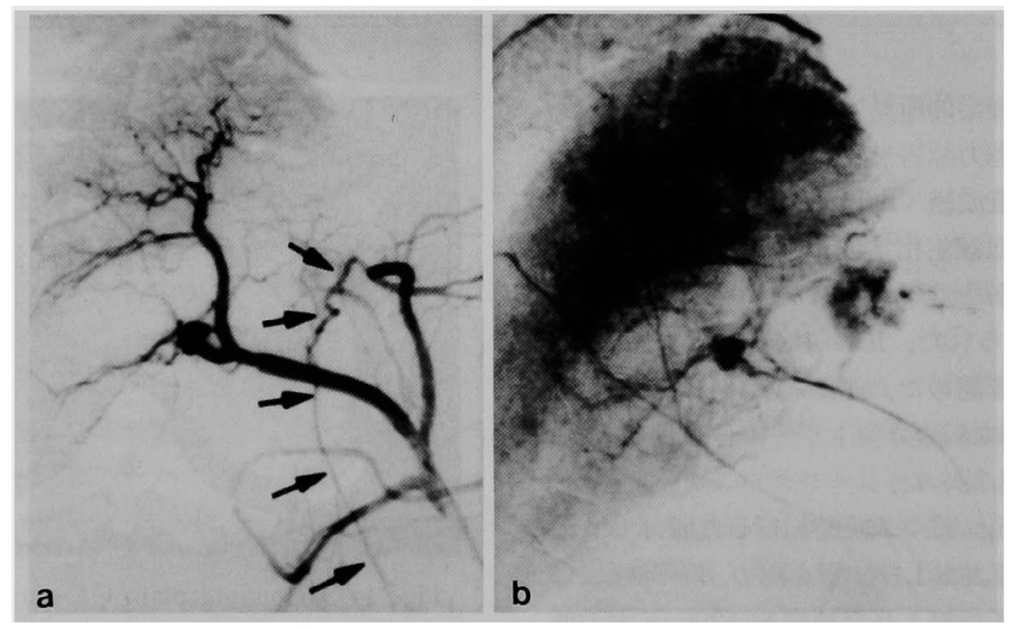

Fig. 3 The hepatic arteriogram at the second time.

$a$ : The hepatic falciform artery (arrow) was seen. b: The primary lesion had disappeared. Another new one in segment 1 of the liver, approximately $20 \mathrm{~mm}$ in diameter, was seen.

に認めた(Fig. 3b). そのため, 左肝動脈内側枝から分 岐する腫場栄養動脈より塩酸 epirubicin $40 \mathrm{mg}$, lipiodol $4 \mathrm{~m} l$ の䀣濁腹を用いて chemolipiodolization を施行したが,この時に塩酸 epirubicin と lipiodol の 䱈濁液の一部が左肝動脈内側枝と外側枝の分岐部近傍 から分岐する hepatic falciform artery へ流入した. 術直後より発熱および心䆚部痛が出現し, 加えて術後
4 日目には上腹部に皮下組織買死と考えられる長径 15 $\mathrm{cm}$ 大の皮下に出血斑を伴う有痛性の硬結を認めた (Fig. 4). chemolipiodolization 後に出現した心简部 痛および白血球増多は，抗生剤とステロイド製侴の使 用にて直ちに改善したが，有痛性の硬結および微熱は 持続し, 症状消失には約 4 週間を要した (Fig. 5), 退 院後自覚症状なく経過したが, AFP 值の改善はみられ 


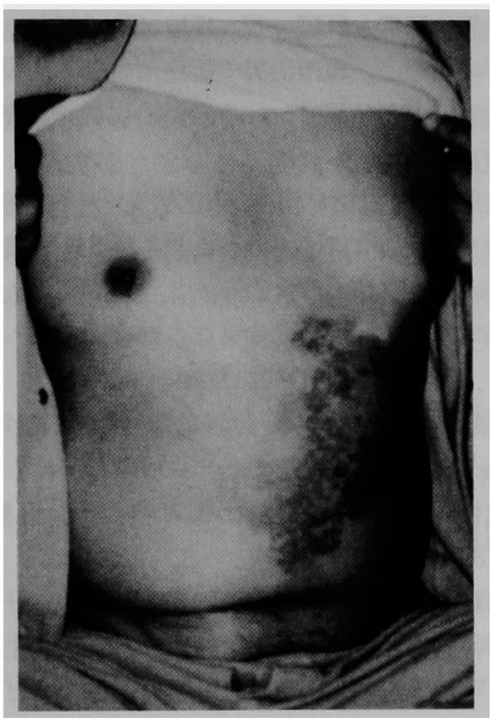

Fig. 4 Photograph of the patient's abdomen. The painful induration with subcutaneous hemorrage, approximately $15 \mathrm{~cm}$ in diameter, was seen on the supraumbilical region.

ず，翌1994年 5 月に第三回肝動脈造影目的に入院と なった。1994年 5 月12日施行の三回目の肝動脈造影で
は, 前回の治療効果は得られておらず, 肝 Sl領域に径 $20 \mathrm{~mm}$ 大の腫湯濃染像を認めたため, 前回と同様の追 加療法を行った．今回は hepatic falciform artery は 途絶しており，造影されなかった (Fig. 6)。その後も 肝細胞癌に対して血管カテーテル治療を繰り返してい るが，同様の皮闫合併症の再発结認めていない.

$$
\text { 考按 }
$$

本症例は肝動脈造影の際に左肝動脈より分枝し肝円 索に伴行する hepatic falciform artery と思われる細 い動脈枝を認めており，左肝動脈内側枝より分岐した 細い動脈枝より血流を供給されている肝細胞癌に対 し，左肝動脈内側枝中枢側より chemolipiodolization を行ったがこの時に塩酸 epirubicin と lipiodol の㦟 濁液が hepatic falciform arteryに一部流入し, 血流 の支配領域てある上腹部皮下組織に血行障害と化学毒 性により壊死を来したものと考えられる。これまでに 肝外臟器として胆䚻 ${ }^{7-99}$, 胃・食道などの消化管 ${ }^{10,11)}$, 脾臓 ${ }^{22}$ の合併症が少なからず報告されており，これら

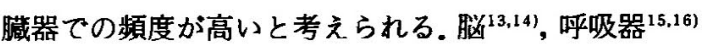
における合併症の報告も散見されるが，本症例のよう な皮成合併症の報告は稀である．現在のところ Williams ら ${ }^{17} に よ る$ 抗癌剤の持続動注後に脺上部皮疹が

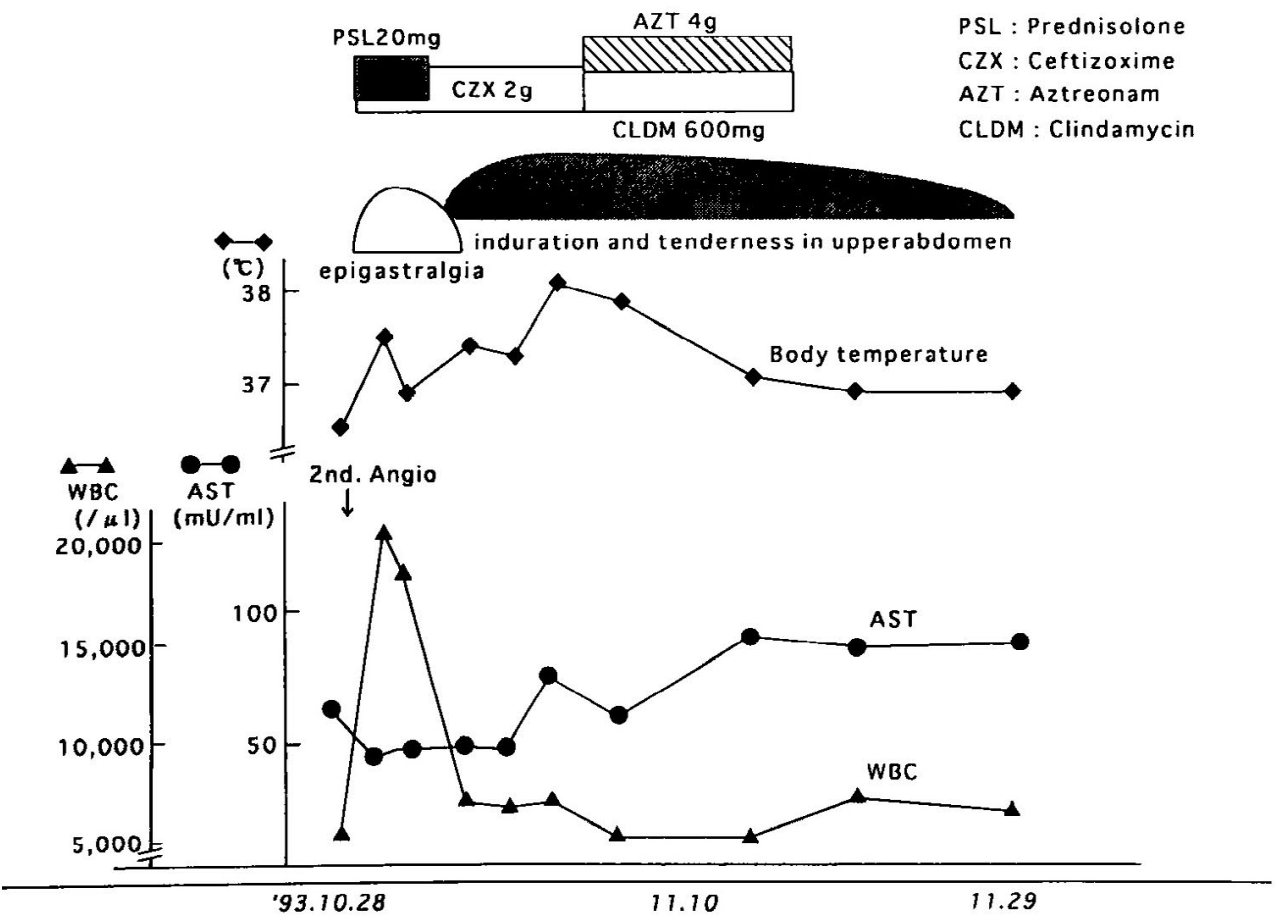

Fig. 5 Clinical course after chemolipiodolization. 


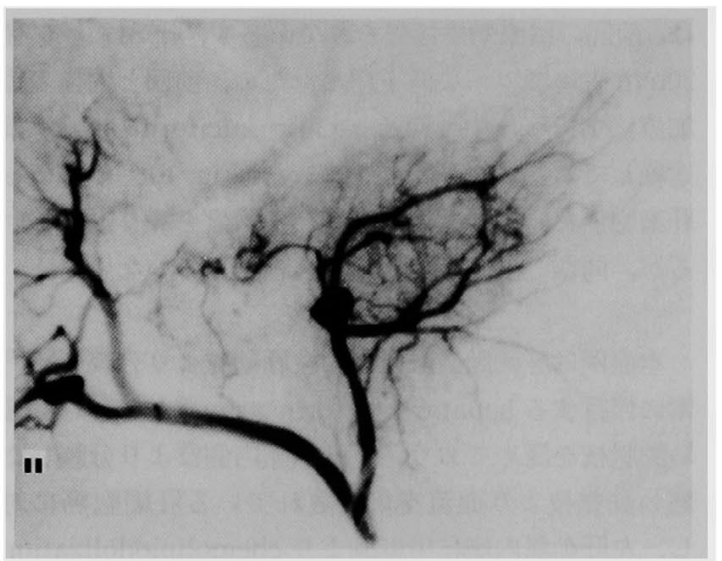

Fig. 6 The hepatic arteriogram at the third time. The hepatic falciform artery was not shown on any picture.

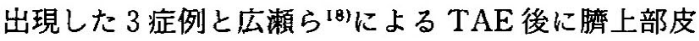
膚の紅斑がみられた 1 症例のみである。これらの症例 はいずれも肝動脈造影時に hepatic falciform artery が描出されている、Williamsらの報告によれば, 肝動 脈造影時に当該動脈が造影される頻度は $2 \%{ }^{171}$ と低頻 度であるものの、この動脈枝の存在を見逃している場 合も少なくないと思かれる。報告例と同様に本症例も 血管カテーテル治療後に生ずる皮㲊合併症と hepatic falciform artery との関連性が示唆された。本症例で は治療内容より化学毒性と虚血が考えられた。

肝細胞癌に対する血管カテーテル治療の際には，力 テーテル先端をより選択的に目的領域に到達させるこ とはいうまでもないが，本合併症は肝円索に伴行する hepatic falciform artery を確認することにより, 回避 あるいは予測しうるものと考えられた。

\section{まとめ}

今回呈示した肝細胞癌に対する血管カテーテル治療 の際にみられた皮䖉合併症の頻度は稀ではあるもの の，上腹部皮下組織の血流を支配する hepatic falciform artery を認めた症例ではこの動脈枝に影響が 及ばないように留意すべきものと考えられた。

\section{文献}

1) 大石 元, 打田日出夫, 大上庄一, 他：肝細胞癌に 対する抗癌剂混入 Lipiodol 併用TAEによる竝 断と塞栓効果一肝切除例からみた検討一。肝臟 $27: 28-35,1986$

2）神野健二, 森脇昭介, 徳山勝之, 他：肝細胞癌にお ける Lipiodol の腫瘄内停滞に関する臨床的病理
形態的研究. 肝臓 $27: 471-479,1986$

3）伊坪真理子, 龟田治男：抗癌剂の動脈内投与一そ の実際と各領域における治療の現況一，癌と化学 㙩法 16:199, 1989

4）松尾尚樹, 打田日出夫, 宗田滋夫, 他：肝細胞癌に 対する抗癌剤混入 Lipiodol 注入担癌区域塞栓術 (Segmental Lp-TAE) 後の切除例からみた病理組 織学的研究一抗腫瘍効果ならびに非癌部への影響 一. 肝臟 29: $54-62,1990$

5）上野敬司，中尾宣夫, 大西光典, 他：原発性肝細胞 癌TAEにおけるリピオドールの有用性一Cox の 比例ハザードモデルによる检討一. 肝臓 31 ： $1186-1190,1990$

6）西村幸洋, 打田日出夫, 松尾尚樹, 他：肝細胞癌 1075例に対する肝動脈塞拴術, 特に累積生存率と 3 年以上生存 69 例からみた抗癌剂混入リピオドー ル併用の評価。癌治学会誌 $26: 2279-2289,1991$

7) Eugene $Y$, Jackson J, Finn JP, et al: Acalculous cholecystitis complicating hepatic intraarterial lipiodol : case report, Cardiovasc Intervent Radiol 12:80-82, 1989

8) Takayasu K, Moriyama N, Muramatsu Y, et al: Gallbladder infarction after hepatic artery embolization. AJR 144 : 135-138, 1985

9) Kuroda C, Iwasaki M, Tanaka T, et al: Gallbladder infarction following hepatic transcatheter arterial embolization. Radiology 149 : 8589,1983

10）池田健次, 熊田博光, 荒瀬康司, 他 : 肝動脈塞栓術 に伴う胃・十二指腸病変 -86 例の治療前後の内視 鏡所見と発生病変の内視鏡的分類一. Gastroenterol Endosc 30:683-690, 1988

11）土亀直俊, 吉松俊治, 緒方義也, 他：TAE 後リピ オドールの逆流をCTにて確認しえた 1 例. 臨放 $36: 505-508,1991$

12) Takayasu K, Moriyama N. Muramatsu Y, et al : Splenic infarction, a complication of transcatheter hepatic arterial embolization for liver malignancies. Radiology 151 : 371-375, 1984

13）柴山隆男, 高橋元一郎, 前田義治, 他：LipiodolTAE 後, Lipiodol の大偱瑵への移行を来した肝 細胞癌の 1 例。肝臓 $30: 484-491,1989$

14）小俣 香, 村上隆介, 大矢 徹, 他：下横隔動脈の TAE 後脳内に Lipiodol の販留を認めた肝癌の 1 例. 臨放 $36: 1187-1190,1991$

15）鮫島仁彦, 田村正三, 小玉隆男, 他：肝細胞癌の動 
注後に肺傷害を来した1例．日本医放会誌 50 ： $24-28,1990$

16）里康 光,一瀬広道, 野田雅也, 他：肝動脈塞栓術 後, 呼吸不全に陥った 1 症例. ICU と CCU 16 ： 1121-1125, 1992

17) Williams DM, Cho KJ, Ensminger WD, et al: Hepatic falciform artery: Anatomy, angiogra- phic appearance, and clinical significance. Radiology 156: 339-340, 1985

18）広瀬仁一郎, 松井 修, 重山富明, 他：肝細胞癌の TAE (Lipiodol, Adriamycin 合) 合併した䏽上部 皮增赤斑の1例. 日本血管造影・Interventional Radiology 研究会雑誌 $1: 34-35,1986$

\title{
A case of hepatocelluler carcinoma with subcutaneous necrosis on upper abdominal wall after chemolipiodolization therapy
}

\author{
Kazuhiko KoIkE, Mariko ITsubo, Masaki HARA, Yasuyuki ENomoto, \\ Jyoji OKuda, Atsushi HoKari, Yasushi OKuaki, \\ Masami SAKAGUCHI, Tomonobu KaWABE and Gotarou TODA*
}

The patient was a 57 -year-old man who had been treated as an outpatient for liver cirrhosis caused by hepatitis $C$ virus and excessive alcohol consumption. An elevated serum AFP level and a mass in the liver on abdominal ultrasonography were noted. A hypervascular tumor was seen in segment 8 of the liver on hepatic arteriography, hepatocellular carcinoma was diagnosed and hepatic arterial embolization was performed. The serum AFP level decreased and rose again after 4 months. On the second angiography, a new tumor was observed and chemolipiodolization was performed in segment 1 of the liver. Four days after treatment, subcutaneous tissue necrosis developed in his upper abdomen. It this patient, an arterial branch considered to be the hepatic falciform artery accompanying the round ligament of the liver and branching from the left hepatic artery was imaged on hepatic arteriography. Therefore, it is considered the necrosis was caused mainly by loss of blood supply in the territory of this artery after chemolipiodolization. This interesting patient with an extremely rare complication is reported here.

\footnotetext{
* Department of Internal Medicine (I), The Jikei University School of Medicine (Tokyo)
} 